International Journal of Instruction e-ISSN: 1308-1470 • www.e-iji.net

Article submission code: 20201212000020

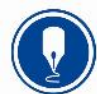

October $2021 \bullet$ Vol.14, No.4

p-ISSN: 1694-609X

pp. 337-356

Received: 12/12/2020

Revision: 14/03/2021
Accepted: 07/04/2021

OnlineFirst: 17/07/2021

\title{
Thai Seven Year Old Early Learner Creativity Design and Study Activities Promotion
}

\section{Suthasini Bureekhampun}

Dr., Faculty of Industrial Education and Technology, King Mongkut's Institute of Technology Ladkrabang (KMITL), Bangkok, Thailand, suthasini.bu@kmitl.ac.th

\section{Kittikorn Techakarnjanakij}

Faculty of Industrial Education and Technology, King Mongkut's Institute of Technology Ladkrabang (KMITL), Bangkok, Thailand, kittikorntech@gmail.com

\section{Piya Supavarasuwat}

Faculty of Industrial Education and Technology, King Mongkut's Institute of Technology Ladkrabang (KMITL), Bangkok, Thailand, piya.su@kmitl.ac.th

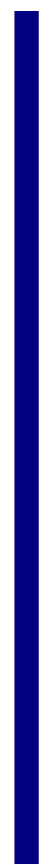

The objectives of the research were to investigate a creative learning promotion activity package for 30 Thai seven-year-old, first-grade school students. Secondly, to design a creative learning promotion activity package, followed by an assessment of the creative learning development process from a series of creative learning promotion activities, and finally, to study the level of parental satisfaction from the final model's related student activities. Additional analysis was undertaken by a group of three child behavioral and learning development experts, and three design experts using a specific selection method. The sample consisted of 30 primary school seven-year-old early learners and 30 parents who were selected by the use of the quota selection method and purposive sampling. The research instruments used included interview forms, product model evaluation questionnaires, behavioral observation forms, and parent satisfaction questionnaires. The results of the research showed that thinking development (TD), physical development (PD), emotional development (ED), and social development (SD) on creativity were affected by a broad spectrum of factors. These included the child's understanding of their surroundings, the use of fine hand muscles, their ability to perform more complex activities, their cheerfulness, social activity, and peer activities, and their ability to concentrate on activities for longer periods. One instrument used for the study included the analysis of five-game board formats used for the development in TD, PD, ED, and SD. The results of the evaluation from the study's product experts determined that style model 3 (Magician's Castle set) was very suitable.

Keywords: activity sets, creative design, creativity, first grade, learning achievement, learning promotion, primary school students, Thailand

Citation: Bureekhampun, S., Techakarnjanakij, K., \& Supavarasuwat, P. (2021). Thai seven year old early learner creativity design and study activities promotion. International Journal of Instruction, 14(4), 337-356. https://doi.org/10.29333/iji.2021.14420a 


\section{INTRODUCTION}

Human learning is born from the surrounding environment. Students learn in different styles, with individual learning styles differing according to each student's experience, nature, and learning methods. To make learning compatible and meaningful for early learners, the literature recommends personalizing the learning environment to meet each student's different needs and characteristics (Chiang, 2016; Ismaeel \& Al Mulhim, 2019; Shahsavar \& Hoon, 2011; Tayebinik \& Puteh, 2013).

Piaget also stated that 'every exchange between the child and his environment tends towards adaption', as well as intelligence, with the beginning of thinking in the context of adaptation (Fleer, 2018).

This allows children to think, act, and solve problems as childhood learning is essential to cultivate children to thrive with quality and be the foundation for their future life. This is supported by the Montessori approach to early learner education which was founded in 1907 by the first Italian female physician, Dr. Maria Montessori. In her constructivist or 'discovery' model, early learners embrace concepts from working with materials (hands-on), rather than by direct instruction (Isaacs, 2018). This is supported in a study of five-year-old Iranian children (Ahmadpour \& Mujembari, 2015), in which it was reported that the IQ and the level of children educated through the Montessori approach were significantly higher than that of the children educated based on the traditional approach.

Furthermore, numerous Thai government documents and supporting studies indicate that today's school-age children aged 6-12 will be a vital and valuable force in the development of the Thai nation in the future. Within this age group, children's capacity for learning is significant, which also stimulates the functioning and development of the brain. As such, children are spending most of their time in school and have to adjust to their studies, school rules, and social norms expected from children of this age. It is also a time in which children must adapt to their teachers and peers. As such, change is accelerated as first graders are additionally rapidly developing physical, mental, cognitive, and problem-solving abilities. It is also now expected that these seven-yearolds start applying the knowledge they acquire, which leads to confidence building, which then leads to stable emotional backgrounds, happiness, and comfortable school life.

But if development during this age is disrupted or some problems are not helped and resolved, the adolescent development stage will become negatively affected, culminating in larger problems in the future. Therefore, in what has been called Thailand 4.0, initiatives are underway to adjust to realistic social conditions, while refocusing on students' ability to achieve general and global knowledge, situational awareness, real-world economic problems, societal issues, the environment, technology use, and knowledge necessary for each student's future career path. Therefore, each student must have systematic thinking skills that can connect all these elements (Abdyrov et al., 2016; Arnold \& Wade, 2017), by use of effective communication, planning analysis, critical thinking, creativity, and relationship development skills. 
These factors successfully executed will lead to sustainable development and lifelong learning (Dağgöl, 2017; Dere, 2019; Laal \& Salamati, 2012).

\section{LITERATURE REVIEW}

\section{Creativity and learning}

According to Trilling and Fadel (2009), the need for creative problem solving as a skill is clear, with the act of being creative indicating you are thinking (Im et al., 2015). However, Bloom ranked synthesis (creativity) as one of the most difficult skills to master, because individuals have to use all of their other cognitive skills in the creative process. Also, creativity is at the highest order of thinking according to Bloom (Halupa, 2016), and it is therefore at the forefront of all learning environments and an end goal.

In a systematic review of 210 pieces of educational research relating to a child's creative environment and learning, Davies et al. (2012) determined that creativity requires the need for time and space flexibility, material ease of access, extracurricular activities, and 'playful' or 'games-based' approaches with a degree of learner autonomy in creative childhood activities. This is consistent with Honig (2020) who observed that creative power increases a young child's desire to learn and supports intellectual development, with creative thinking implicit in many cooperative games. Göttel (2009) even suggested that in Hamburg, Germany where multi-cultural classrooms predominate, having students create participatory games and stories is an excellent tool for teaching creativity. Therefore, the organization of creative thinking activities should be flexible, so that the learners can express their imagination to the fullest extent possible.

There is also a significant body of evidence that suggests that creativity is directly related to problem-solving skills, which is critical in a $21^{\text {st }}$ Century workforce (Beghetto, 2019; Im et al., 2015). Fortunately, scholars have suggested that creativity can be taught in a classroom (Karpova et al., 2011), with the frequently used Torrance Test of Creative Thinking (TTCT) using timed drawing activities of picture construction, picture completion, and lines/circles as creativity assessment exercises (Radiah, 2020, Yarbrough, 2016).

\section{Creative learning activities}

First and foremost, creativity does not involve 'chalk and talk'. Classroom creativity education is about student-centered activities which entail a teacher's passion for what is being taught. Creativity also involves innovation, 'out-of-the-box' thinking, and improvisation (Riche, 2014). Also, according to Gielen (2009), play is normally focused on 'aimlessness', which is the player motivated for the activity by an interest in the process, not by a desire for a certain lasting outcome.

Also, a search of the Internet will find countless educators listing off their favorite digital creativity tools and learning management systems (LMSs). However, one thing that is consistent across them all is the use of social media platforms and smartphones to deliver the content both ways (Yuktirat et al., 2018).

One fascinating study by a Thai artist and educator details how she uses mobile learning (M-learning) on a smartphone to teach the 'magic of art' and the art of drawing online through the Facebook social media platform (Yuktirat et al., 2018). Her methods are 
also very similar to Austria's ePortfolio initiatives which are now a key element in the country's national learning policies (Dorninger \& Schrack, 2008). This is also consistent with Girmen and Kaya (2019) in Turkey who used WhatsApp to exchange digital storytelling.

However, for early learners who are confined to a classroom, 'hands-on' creativity exercises still wins the day with 'art', in its various forms and mediums a good starting point in the development of creative human skills and knowledge. It has also been suggested even before young children learn to read and write, exposure to the arts enables them to express representative and abstract thinking. Farokhi and Hashemi (2011) also added that children explore the world around them through intellectual, physical, and emotional methods, with paper, a pencil, or brush the best tools in conveying their fondest hopes and most profound fears.

Moreover, color can help children develop vocabulary, complex thinking, and keen observation (Morse, 2017). Also, painting has been described as a creative path to the dimension of imagination (Yuktirat et al., 2018), which helps one search for identity, creates happiness, and protects the identity of the drawer. Space is also critical in indoor creativity exercises as studies suggest that a child's play environment should have 30 50 square feet of usable space per child represents an ideal size for indoor environments (Biddle et al., 2013). Spaces with less than 25 square feet per child generally lead to increases in aggression and unfocused behavior for children.

In Japan and other countries throughout Asia, origami paper art is used to teach creativity to children. However, many western childhood educators might be confused as to how a rigid, teacher-initiated and directed, non-individualized, product-driven activity is 'creativity'. The answer lies in the Japanese words which translate as 'path' or 'way' and 'form'. In this creativity exercise, all Japanese children are taught this method as a way to master forms and rules, then extending them, and finally breaking the rules and playing with established forms. These assumptions of Japanese art and aesthetics are mirrored in the pedagogy of origami lessons (Sefton-Green et al., 2011). Similarities exist within Thai creativity education activities as well.

\section{Playing activities}

Play has also been stated to hold an important role in the progress of childhood development (Sandborn, 2014). Plato has also been attributed as saying that one can discover more about a person in an hour of play than in a year of conversation (McFarlane, 2013).

Furthermore, play value is a term used to describe the overall enjoyment of a child with a certain toy, which includes factors such as complexity and challenge, context appropriateness, and correspondence to the character of the child (Gielen, 2009; Gielen and van Leeuwen, 2013). Play is also a very open-ended activity with play characterized by its many degrees of freedom in its nature, performance, and contents. In Turkey, Girmen and Kaya (2019) stated that games were important tools that people have used for different purposes at every stage of their life, with properly designed games being an effective tool to positively affect each student's desire for participation, interest, 
attitudes, motivation, and success (Alsawaier, 2018; Su \& Cheng, 2015). Finally, to quote Gielen (2009), "A toy is a tool for play, and it must be a useful tool."

\section{Research Questions}

Therefore, the current research investigates creative activity promotion on Thai sevenyear-old school children, and the related and subsequent impact and opinions on their parents and caretakers. Therefore, the research investigates the following questions:

- What themes promote creative learning in Thai seven-year-old school children?

- What forms of activity designs promote their creative learning?

- What activities should be used to access their development from the use of a series of creative learning promotion activities?

- What level of parent satisfaction is achieved from the study's creative learning promotion activities?

\section{METHOD}

This study intended to study and design a series of play activities promoting creative learning for seven-year-old Thai school children. The focus was given to how these activities were affected by each child's thinking development (TD), physical development (PD), emotional development (ED), and social development (SD). Additionally, each model iteration and activity consisted of the use of points, lines, shapes, colors, and various experimental materials (e.g. clay, paper, wood). All these factors when applied to the art or play activity foster creative thinking, which also enhances a child's physical and sensory coordination. Being able to express one's thoughts through painting, drawing, tearing, paper folding/cutting, clay sculpting, or scrap material fabrication, can significantly enhance creative thinking.

\section{Participants}

For the study, a total of nine experts were involved in assessing various elements within the research. These nine individuals were divided into three groups three. There was also a group of 30 children and 30 parents, for a total of 69 participants in the study.

\section{Expert Group 1 - Questionnaire Development}

Three experts who were authorities on seven-year-old child behavior and child development assisted with the study's analysis. The first expert was the owner of the Academy of Art Studio \& Gallery in Bangkok, Thailand. The second expert was a primary school art teacher at the Siriwat Wittaya School in Bangkok. The third expert was a senior training officer with the True Click Life Unit in Bangkok who was responsible for the creation of teaching and learning materials. Additionally, each expert had a minimum of five years of related work experience.

\section{Expert Group 2 - Design Evaluation}

Three individuals participated as experts to evaluate the study's prototype, including the packaging and graphic design. Expert 1 was a Senior Design Executive at True Click Life. Expert 2 was a lecturer in the Department of Product Design at the College of Engineering in the Rajamangala University of Technology in Rattanakosin, Thailand. Expert 3 was also a Lecturer of Product Design in the Faculty of Architecture and 
Design at the Rajamangala University of Technology in Phra Nakhon, Thailand. Additionally, each expert had a minimum of five years of related work experience.

\section{Expert Group 3 - Final Research Experiment}

Three individuals participated as experts to evaluate the study's final research experiment of 30 children. Expert 1 was an Assistant Professor and Lecturer of Art Education Program in the Faculty of Education at Chulalongkorn University in Bangkok. Expert 2 was also an Assistant Professor and a board game designer. Expert 3 was a professional freelance designer. Additionally, each expert had a minimum of five years of related work experience.

Moreover, 30 seven-year-old Thai primary school (Prathom Suksa) students who were enrolled in the first grade of Watplooksattha School, Ladkrabang District Office, Bangkok, Thailand participated in the study. The research experiment was conducted on August 13, 2020, from 9.00-12.00, with 20 minutes allocated to each student playgroup, with three groups of playtime. Each of the three playgroups contained $3-6$ players per group.

Additionally, 30 parents of elementary school students in the first grade of Watplooksattha School, Ladkrabang District Office, Bangkok, Thailand were used as a sample from a potential population of 76 first grade school parents.

\section{Research design and framework}

The authors identified four conceptual areas (TD, PD, ED, and SD) from the literature and theory, for possible use in activities promoting seven-year-old child creative learning.

\section{Research tools}

The research tools used to collect information for the study's analysis were a series of activities promoting creative learning for seven-year-old children.

Additionally, the researchers collected data from expert interviews, which used structured interviews with open-ended questions. Questionnaires were outlined according to the research objectives.

After the analysis of the first phase of interviews, secondary interviews were arranged in which further questions expanded on the knowledge previously gained. Questioning involved the design and creative learning promotion concepts for seven-year-old children as outlined in the BTEC first children's care (2006) handbook and similar discussion in the UK from Smith et al. (2015).

\section{Data collection, reliability assessment, and validity testing}

The researcher used both secondary and primary data collection methods to summarize and analyze relevant issues. To guide the design, the analysis used qualitative data employing an essay narrative.

To study the satisfaction of the 30 parents with the children's activities, a selfadministered questionnaire (SAQ) was used which contained both closed-ended and 
open-ended questions. Moreover, the questionnaire consisted of three parts. These included Part 1's General Information of the Respondent, Part 2's Parents' Satisfaction with Seven-Year-Old Childhood Learning Promotion Activities which used a 5-level assessment scale, and finally, Part 3's Further Suggestions.

As such, Drost, E. (2011) has stated that in psychological testing of attributes or behaviors, reliability evaluation should be undertaken which is simply the consistency of measurement or stability of measurement over a variety of conditions in which the same approximate results should be obtained. Additionally, according to Chuenban et al. (2021), content validity (CV) should be assessed after a questionnaire's design, with a study's design strength or CV strongly dependent on how accurately the variables which have been selected are measured (Price et al., 2019). This is because even though a study can have a reliable measurement, it does not necessarily indicate a valid measurement. Therefore, an expert team of three individuals was selected (Expert Team 1) to review and assess each of the questionnaire's items, with CV measurement using the often cited criteria of indexes of item-objective congruence (IOC) $\geq 0.50$ (Pimdee, 2020). Additional checks and amendments were made to ensure correctness.

Subsequently, the questionnaire was used to determine the level of satisfaction of the 30 parents selected for the study's sample group of 30 seven-year-old students. To determine the importance and a summary of each variable, descriptive statistics were used. Standard testing includes analysis for the mean $(\bar{x})$ and the standard deviation (S.D.) (Boonkua et al., 2020; Yuktirat et al., 2018).

\section{Area 1 - Themes}

Area 1's conceptual framework intent was to study the themes used in a series of activities promoting creative learning for seven-year-old school children. The conceptual framework for these tasks was adopted from the BTEC first children's care (2006) handbook, which is related to children's development in the four areas of TD, $\mathrm{PD}$, ED, and SD. Moreover, the format for learning promotion activities for creative children used suggestions outlined for early learners from the Ministry of Education. (2013) in Singapore, which consists of points, lines, shapes, colors, and textures. Art is an activity that fosters creative thinking and invites the senses between hands and eyes. Knowing to use one's thoughts in various expressions such as painting, drawing, tearing, paper cutting, clay sculpting, fabrication of scrap materials, etc., enhances these processes.

\section{Area 2 - Design}

Area 2's conceptual framework intent was to study a series of activities promoting creative learning for seven-year-old children, from which 12 elements were identified (Jai-ai et al., 2019). These included (1) functionality, (2) safety, (3) durability, (4) economics, (5) materials, (6) construction, (7) ergonomics, (8) aesthetics, (9) personality, (10) production, (11) maintainability and (12) transportability.

Furthermore, intelligence, emotion, social and physical characteristics were also identified as essential in the design of activity sets. These included; 
(1) Physical development (PD) - Larger muscle and small motor development can be improved by the selection of the right activities and their associated toys. Activity sets include paper cutting, crafting, drawing, painting, etc.

(2) Social development (SD) - Playing helps children adapt to the environment, allowing for the foundation of friendship laying amongst classmates. It can also create an atmosphere of generosity and sharing, the ability to sacrifice and the acceptance of others' opinions of others, patience, etc.

(3) Emotional and mental development (ED) - Playing is a stress reliever in children's daily life. This allows children to adjust their emotions and feelings.

(4) Intelligence or thinking development (TD) - Playing fosters learning and playing and helps focus on the child's perception of the environment.

Area 3 -Activities

Area 3 was concerned with the conceptual framework in the assessment of creative development for activities promoting creative learning. The researchers used evaluation criteria from which a checklist was developed as an assessment tool in a series of creative learning-promotion activities. This technique is supported by research from Lowenfeld and Brittain (1987) who reported that the progression of drawings that children makeover some time can show significant growth and development, as well as determines academic capabilities and skills characteristic of their developmental level. It is through their drawings that children express the views and interpretations of their experiences (Farokhi \& Hashemi, 2011).

Meerum-Terwogt and Hoeksma (1995) also determined that seven-year-olds preferred the color blue the most, followed by yellow, red, white, green, or black. This is consistent with Lowenfeld and Brittain (1987) who noted that primary school children can be expressive and spontaneous in the colors that they choose in their drawings, as well as their use of points, lines, and shapes. Drosinos' (2006) subsequent study in the US confirmed this.

\section{Area 4 - Parent satisfaction}

Areas 4's conceptualization was rooted in the research provided by various authors in the field of design. From these studies, four elements were determined to stand out in their importance as guiding principles for satisfaction evaluation in educational creativity tool design. These elements included: (1) functionality (2) safety (3) ergonomics (4), and aesthetics (Okulova, 2020; Wormald \& Rodber, 2008). Thus they were used for the evaluation process by parents and caretakers of the study.

\section{Instruments}

\section{Creative learning activity pattern analysis tools}

From the analysis of patterns of creative learning activities for seven-year-old children, 12 types of activity sets were identified, these included; 1 . art activity set, 2. 3D bead set, 3. magnetic puzzle, 4. a large set of mixed color art, 5. bolt set per picture, 6 . an 
alternate color block, 7. alternating woodblocks, 8. leaf and sliver drawing and painting kits, 9. various shapes molding sets, 10. board games, 11. Complex visual board games, and 12. alphabet rubber stamps.

\section{Creative learning activity artistic board game tool}

The creation of an artistic board game activity format helps to promote the development in all four areas of childhood development (TD, PD, ED \& SD). This is consistent with previous studies for seven years olds in which seven characteristics of toy products for children have been identified (Bureekhampun \& Tecchakanjanakij, 2019). These include; (1) toy type, (2) style of play, (3) features (4) usefulness, (5) safety, (6) efficiency, (7) savings, and (8) restrictions. Finally, Figure 1 also displays the results of the 30 conceptual sketch ideas and elements analysis, in which the researchers drew initial concepts from the study's analysis of the data.

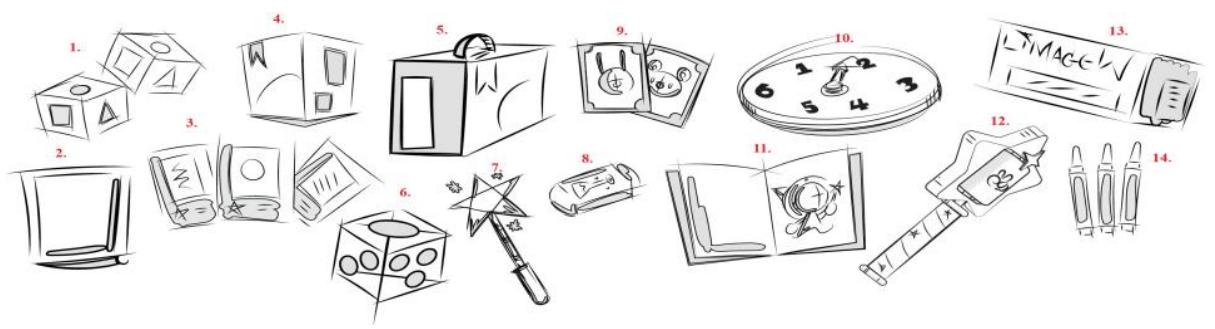

Figure 1

A selection of 14 items used in the initial sketch design for the model's development

\section{Product design development idea evolution}

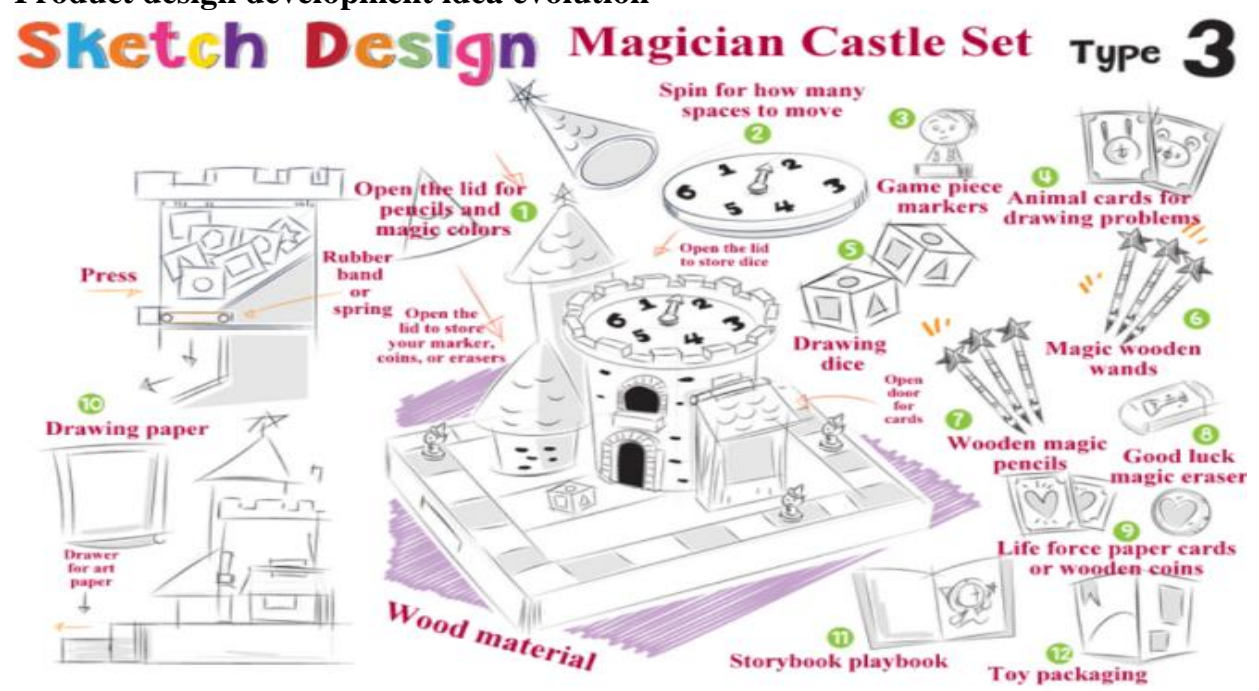

Figure 2

Style type 3 product sketch design selection winner 
Initially, 20 conceptual complete game activity designs were conceived. From these, five model styles were selected for further analysis to find the most suitable style (Bureekhampun \& Tecchakanjanakij, 2019). Thereafter, from the five models selected for further analysis, three product design experts assisted with further evaluation of the most suitable format prototype for the study's series of activities promoting creative learning, from which style type 3 was selected (Figure 2).

The results of the evaluation of the theme of the creative learning promotion package for 7-year-olds were conducted by the product experts in the total evaluation of the 5-yearolds. From this evaluation process, Model 3 in Figure 3 was judged to be very appropriate $(\bar{x}=3.88$, S.D. $=0.72)$. From this initial working design, the researchers went on to improve and develop a working model more suitable for the prototype's production process, as depicted in Figure 3.

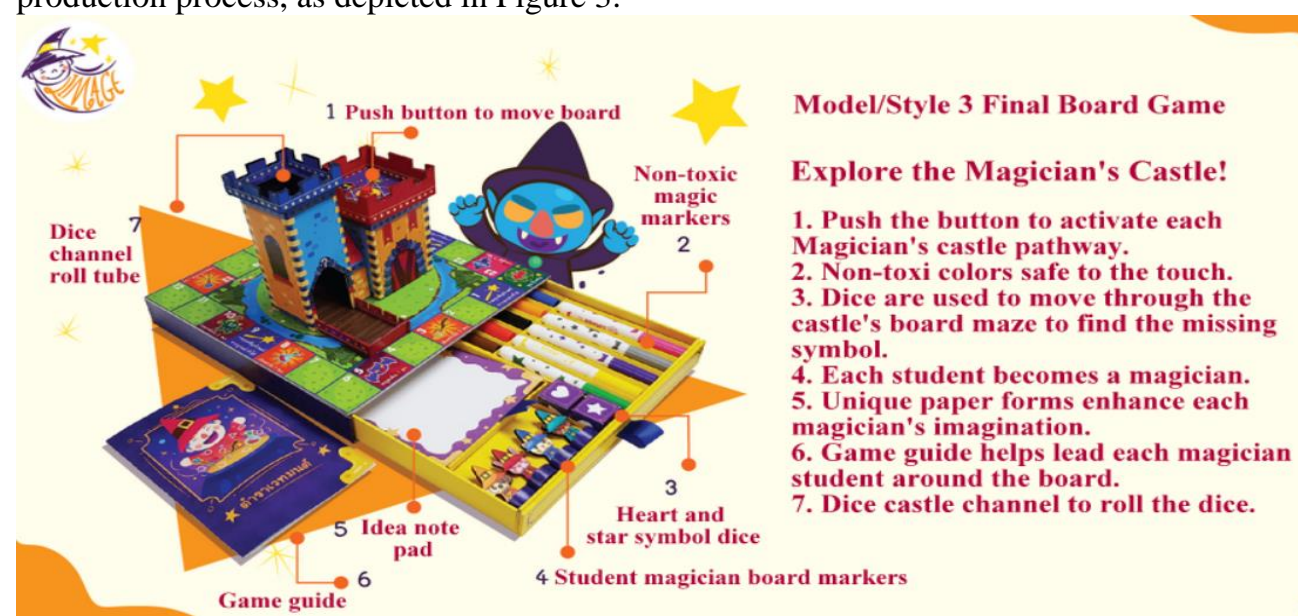

Figure 3

Final activity board game model for the evaluation of seven-year-old creativity development

\section{FINDINGS AND DISCUSSION}

This section is presented in six parts, which will hopefully answer and detail the study's four main research questions and additional testing results, with Part 1 presenting the information concerning the creative learning developmental characteristic themes the study investigated for seven-year-old Thai school children. Part 2 presents the analysis details on which type of activity design promotes each child's creative learning. In Part 3 we find which creative learning promotion activities are best. In Part 4 the results from the evaluation of the levels of parent satisfaction from the study's creative learning investigation are detailed.

Part 5 additionally adds the results from the experts' observations of an experimental group of six children. In Part 6 the results determined from the final children's participation group of 30 children are detailed. 


\section{Part 1 - Developmental characteristic themes}

Table 1 presents the findings from the main developmental characteristic themes selected for the study's analysis. These included a child's thinking development (TD), physical development (PD), emotional development (ED), and social development (SD).

Table 1

Analysis results from related seven-year-old behavioral and child development studies

\begin{tabular}{ll}
\hline $\begin{array}{l}\text { Developmental } \\
\text { characteristic } \\
\text { themes }\end{array}$ & Analysis results \\
\hline $\begin{array}{l}\text { Thinking } \\
\text { Development } \\
\text { (TD) }\end{array}$ & $\begin{array}{l}\text { Seven-year-old children have wider cognitive development ability than children 1- 6- } \\
\text { year-olds. These include reading, writing, and numerical thinking abilities. } \\
\text { Moreover, drawing becomes more detailed, with logical thinking skill improvement. }\end{array}$ \\
\hline $\begin{array}{l}\text { Physical } \\
\text { Development } \\
\text { (PD) }\end{array}$ & $\begin{array}{l}\text { The PD of seven-year-old children is slow and uneventful. However, muscles do } \\
\text { become more powerful. Also, children at this age are sensitive and tend to focus on } \\
\text { activities. These can include complex activities and creative play, such as drawing } \\
\text { and sculpture. }\end{array}$ \\
\hline $\begin{array}{l}\text { Emotional } \\
\text { Development } \\
\text { (ED) }\end{array}$ & $\begin{array}{l}\text { Children today at age of seven are more rational than ever before, with a higher } \\
\text { emotional understanding of others. Peer acceptance is also becoming important, with }\end{array}$ \\
\hline $\begin{array}{l}\text { ED creativity enhanced by sculpting, drawing, and story writing. } \\
\text { Social }\end{array}$ & $\begin{array}{l}\text { Once again, peer acceptance is becoming important at this age, with children often } \\
\text { time joining 'societies', 'clubs', or same-sex friendships. As such, previous selfishness } \\
\text { traits (mine) start to wane, with sharing recognized as a tool for social interaction. } \\
\text { (SD) }\end{array}$ \\
\hline
\end{tabular}

\section{Part 2 - Promoting creative learning activities set design results}

The results of the analysis of materials used to create a series of creative learning activities used commercially available materials and products. From the analysis of the students, it was determined that the most popular materials used in toy products were wood, rubber, plastic, paper, and dough, with the paper being selected as the most appropriate material for the final set design and their artistic imagination. Moreover, the paper is lightweight, has a smooth surface, good pressure support, and is safe to use (Jaiai et al., 2019). Furthermore, from the analysis, the use of a board game-style activity was determined to most appropriate for the sample group's developmental age of severyears-old. The board game activity was found to be suitable for developing thinking suitability and emotional and social skill development,

The results of the data analysis from the children's cognitive questionnaire used to ascertain what were the primary needs of each child were used as a guideline for designing a series of creative learning activities for the sample of Thai seven-year-olds.

First, it was determined that the type of color that children liked the most was blue (40\%). This was consistent with Meerum-Terwogt and Hoeksma (1995) who also determined that seven-year-olds preferred the color blue the most. The most favored categories for the children were land animals $(80 \%)$, followed by aquaculture $(20 \%)$. Preferred locations were cities and castles $(50 \%)$, followed by the sea $(30 \%)$ and the forest $(20 \%)$. This helped in the stimulation of cognition, and the promotion of their imagination and art. Finally, the study's questionnaire was used as a guideline for 
designing a series of creative learning activities for the children's sample group, leading to the next step in the Sketch Idea design process.

Table 2

Analysis results from related seven-year-old behavioral and child development experts

\begin{tabular}{ll}
$\begin{array}{l}\text { Developmental } \\
\text { characteristics }\end{array}$ & Analysis results \\
\hline TD & $\begin{array}{l}\text { A child's TD at seven revolves around their immediate interests, the beginnings of } \\
\text { independent thinking, creative thought, assertiveness, and disregard for danger. Play } \\
\text { is also a form of expressing happiness. }\end{array}$ \\
\hline PD & $\begin{array}{l}\text { Boys tend to exhibit slower PD than girls at this age. However, boys will exhibit } \\
\text { quicker muscle development while girls tend to grow quicker sooner. }\end{array}$ \\
\hline ED & $\begin{array}{l}\text { Seven-year-olds are usually cheerful but emotional, with reasoning seldom used. They } \\
\text { are also often self-willed. }\end{array}$ \\
\hline SD & Children behave similarly, are easy to match, and adapt well. \\
\hline
\end{tabular}

\section{Part 3 - Promoting creative learning activities results}

Table 3

Child behavior activity analysis from observations from the research field trip

\begin{tabular}{ll}
\hline $\begin{array}{l}\text { Developmental } \\
\text { characteristics }\end{array}$ & Analysis results \\
\hline TD & $\begin{array}{l}\text { From observations of seven-year-old children playing and doing art activities, children } \\
\text { are frequently prone to express what they have seen and learned. They will also make } \\
\text { the best effort at attempting to draw what they see, as compared to younger children } \\
\text { who draw using their interpretation of what they see and they like. }\end{array}$ \\
\hline PD & $\begin{array}{l}\text { Children at seven years old also begin to develop good use of fine motor muscle skills. } \\
\text { However, their ability from their analysis to convey the observation is out of } \\
\text { proportion. When it comes to hand-eye coordination at this point, most children try to } \\
\text { look the same. Thus, the realization of failure becomes a problem leading to their } \\
\text { unwillingness at further attempts. }\end{array}$ \\
\hline ED & $\begin{array}{l}\text { At seven years old, children's ED has increased giving them a better ability to } \\
\text { concentrate and do art activities for longer periods than younger children. However, } \\
\text { playtime and other activities along with snacks are considered important still. } \\
\text { Moreover, some children exhibit their independence and want to complete their } \\
\text { activities without rest. At this age, children are also highly active and are, therefore, } \\
\text { prone to hyperactivity and unable to sit still for extended periods. }\end{array}$ \\
\hline Ch & Children who know each other or come together will do activities together. \\
\hline
\end{tabular}

\section{Part 4 - Creative learning activities develop parental evaluation results}

Table 5 details the results of an assessment of parental satisfaction towards a series of creative learning promotion activities for Thai seven-year-old school children as shown in Figure 4. From these activities, it was determined that the sample group's parents had a high level of overall satisfaction with the activities $(\bar{x}=4.40$, S.D. $=0.15)$. When considering each item from the parent's evaluation, colorful activity outfits were deemed to be the most suitable for their children $(\bar{x}=4.83$, S.D. $=0.38)$. These results are consistent with the design principles outlined by Jai-ai et al. (2019), where all four functional areas are useful in play, the activities are safe, are comfortable to use, easily transportable, aesthetically pleasing, and attract attention. 
Table 5

Results of parent satisfaction assessment towards the set of creative learning promotion activities for seven-year-old Thai children

\begin{tabular}{llll}
\hline \multirow{2}{*}{ Parent's assessment list } & \multicolumn{3}{c}{ Satisfaction assessment results $) n=30($} \\
\cline { 2 - 4 } & $\bar{X}$ & S.D. & Satisfaction level \\
\hline The activity set is suitable for a child's size. & 4.33 & 0.61 & Very satisfied \\
\hline Activity sets are useful for children's play. & 4.57 & 0.68 & The most satisfied \\
\hline The activity kit contains materials suitable for children's play. & 4.50 & 0.73 & The most satisfied \\
\hline The activity clothes are strong and durable. & 3.90 & 0.84 & Very satisfied \\
\hline The activity package is safe for children's play. & 4.50 & 0.57 & The most satisfied \\
\hline Activity outfits can be easily stored. & 4.27 & 0.74 & Very satisfied \\
\hline The colorful activity outfits are appropriate for the children. & 4.83 & 0.38 & The most satisfied \\
\hline The activity set is reasonably priced. & 4.27 & 0.78 & Very satisfied \\
\hline Average & 4.40 & 0.15 & Very satisfied \\
\hline
\end{tabular}

\section{Part 5 - Creative learning activities expert observation results}

The results of the three experts' observations of the sample group of children found children are interested in learning how to play with a set of toys to promote creative learning. Also, children have to adapt to how to play within a group of friends. They must learn to understand the rules of play, how to share ideas, express their opinions, and interact with their peers. This is consistent with Eccles (1999), who stated that children at this age are developing a sense of self-esteem and individuality while comparing themselves to their peers.

Group board gameplay also teaches children cause and effect, while also developing patience skills since they are in a group. An additional detail that was revealed from drawing exercises was that children had no difficulty in drawing geometric shapes and freeform shapes as determined by the researchers. The children were also able to build on these shapes and add their imagination and creativity as conveyed by the child's understanding caused by the environment around them, preferences, imaginary pictures, and objects.

It was also established that optimal playtime for each group session was 15 - 25 minutes. Also, results from observing the behavior of the experimental group of six children while testing the overall activity set, found that each child was excited and delighted with the toys they saw.

Moreover, the observation group followed each activity set's rules and regulations well, with each group collaborating on how to play the game. Moreover, some children play fast, while others are slow. There was also a willingness to draw, with the significant effort undertaken to draw both simple and difficult symbols. The children also exhibited mutual learning for their drawing, which can be observed from the pictures drawn in the same way. Additionally, children enjoy the art of drawing that has been found from the role-playing story of the activity set, with everyone collectively assisting with afteractivity clean-up exercises. Finally, product expert evaluations for each of the five proposed models determined that model style 3 was highly appropriate $(\bar{x}=3.88$, S.D. $=$ $0.72)$. 


\section{Part 6 - Creative learning activities development evaluation results}

The researchers led a series of activities promoting creative learning for seven-year-olds that were developed and improved from the initial prototypes. In the sample of 30 seven-year-olds used to evaluate Style 3's (Figure 4) creative development activity kit, each round of children was observed by three experts (Expert Team 3) on children's learning behavior. During this process, observations were recorded on a checklist tool according to the assessment item topic. The results were then accessed using a scoring rubric suggested by Best and Kahn (2016) to interpret the results. The evaluation criteria from the rubric were calculated as follows:

$37.51-45.00$ points $=$ very good.

$30.01-37.50$ points $=$ good

$22.51-30.00$ points $=$ fair

$15.00-22.50$ points $=$ needs improvement

Thereafter, the results were analyzed and are presented in Table 4, with both observation teams reporting 'good' to 'very good' results for both round 1 and round 2 activities. Moreover, it was determined from both observer groups from both evaluation rounds that the children had an average creative development and were consistent in the same direction.

Table 4

The results of the evaluation of the creative development from the set of activities to promote creative learning for seven-year-old Thai school students

\begin{tabular}{llllllllll}
\hline \multirow{2}{*}{ Item } & \multicolumn{3}{c}{ Observation Team 1 } & \multicolumn{2}{c}{ Observation Team 2 } & \multicolumn{3}{c}{ Average } \\
\cline { 2 - 10 } & $\bar{X}$ & S.D. & $\%$ & $\bar{X}$ & S.D. & $\%$ & $\bar{x}$ & S.D. & $\%$ \\
\hline $\begin{array}{l}\text { Round 1 test } \\
\text { results }\end{array}$ & 32.77 & 0.71 & 72.81 & 30.60 & 0.69 & 70.22 & 31.72 & 0.70 & 70.49 \\
\hline $\begin{array}{l}\text { Round 2 test } \\
\text { results }\end{array}$ & 38.07 & 0.50 & 84.59 & 37.33 & 0.50 & 82.96 & 37.70 & 0.50 & 83.78 \\
\hline
\end{tabular}

Figure 4 shows the use of the activity set Style 3 experiment with the sample group.
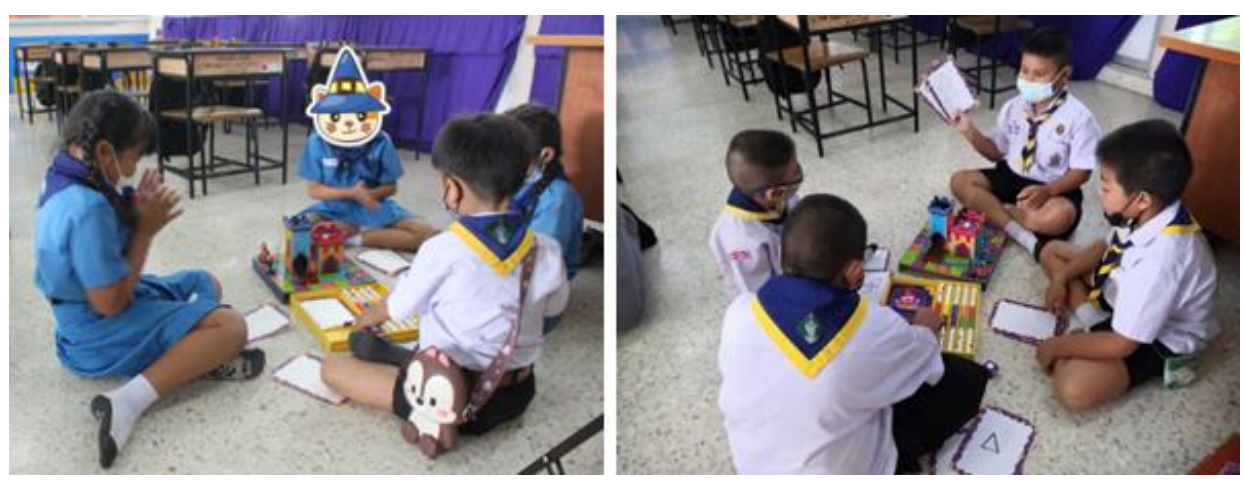

Figure 4

Photos of the Thai children sample group playing with the magician's castle activity board game 
Also, from the study and design of a series of activities promoting creative learning for seven-year-old Thai school children, the researchers determined that from the four aspects related to child behavior and activity patterns, it was found that they exhibit broader thinking, including more interest in their surroundings. Moreover, their use of fine hand muscles was more complex. Additionally, Thai first graders are more apt to exhibit core values which include emotion and cheerfulness, with the ability to adapt easily to society. These factors are consistent with other studies that state that the world of children in middle childhood $(6-14)$ make strides toward adulthood by becoming competent, independent, self-aware, and involved in the world beyond their families (Eccles, 1999).

Moreover, the study pointed out child creative development can be reinforced from the use of colorful, board activity sets, with good activity sets exhibiting characteristics that contribute to thoughtful activities, social learning from group activities, distinctive features that enhance creativity, and imagination in the arts, and finally, activity enjoyment. Moreover, design analysis also embraced the 12 design principles outlined by Jai-ai et al. (2019), with each child's safety a primary concern. An example of this concern was the use of lead-free paint (nontoxic) in each of the five models. Also, the board game's durability and longevity were examined, as well as how suitable the material was for storing and handling by the children. Other factors examined and implemented into the final model included attention-grabbing colors, design uniqueness, and a suitable production process that is easy to maintain.

The suitability of paper in the use of toy design and use was also established, as paper supports playing and doing artistic activities. Paper is also lightweight, has a smooth surface, is excellent for construction projects, is reasonably priced, and is safe for children's use (Jai-ai et al., 2019). This is supported by numerous articles and papers over many decades concerning the use of origami (paper folding art) in creativity (Vargas \& Castro, 2020). The versatility and capacities of Origami paper folding have been used as an appropriate methodology for creating different applications since students can deploy their full creativity and intuition freely and without restrictions that limit their possibilities (Sefton-Green et al., 2011). The study's Magician's Castle activities had similar capabilities and outcomes. As might be expected, first-round children were somewhat slow in accomplishing the exercises but by the time of the $2^{\text {nd }}$ round, were better versed in the process and procedures and did quite better. Overall, the children's mood was happy with the game and their classmates, and was very excited when it was their turn in the game.

Additionally, the study confirmed concepts outlined by Singapore's Ministry of Education (2013) in which creative nurturing of early learners was discussed in terms of 'aesthetics'. Once again, love and pursuit of beauty in art create opportunities for the creative expression of emotions and ideas. In Art, this creativity is expressed through colors, shapes, lines, and various textures from the use of different art media and techniques. Sawyer and Wills (2011) added that a digital story is also artistic, creative, and at the same time an aesthetic product created in a digital format using the possibilities of multimedia tools of a story. 
The study also confirmed a high level of student interest in the Magician's Castle activity design, as they were happy with the design and enthusiastic in their play. Thus, the observation team concluded that the children were open to learning and playing a new game, were quick to learn, enhanced their fine muscle skills in the game drawing exercises, and did quite well in replicating the objective to be drawn. This is consistent with Farokhi and Hashemi (2011) who reported that drawing activities promote expression and the expansion of a child's worldview. By expressing these in pictures, the consciousness becomes entrenched in the child; it enriches the world of creativity and expands the substance of daily life.

\section{CONCLUSION}

Results from the evaluation of creative development activities for Thai seven-year-old Thai school children determined that the sample group of 30 children developed a very good level of imagination and creativity. Additionally, the children showed imagination and creativity in their activity drawing exercise, while also demonstrating good use of dots, lines, and shapes in drawing and painting. They were also able to communicate well with their classmates, including the needed skill of describing a picture drawing activity. Additional importance was also established for the concept of 'creativity space', like art and music, and movement fosters the development of the whole child, including the cognitive, physical, social-emotional, and creative domains. Educators seeking to nurture creativity should provide a range of stimuli, ideas, and opportunities for children to draw, paint, print, create collages, and construct 3-dimensional structures. As the creative process is not always instant and children need time to work on their ideas and creations, there should be sufficient time and space for them to explore a diverse repertoire of art media and techniques. Finally, the student's parents from the study had a high level of satisfaction for the prototype creativity board game and rated the costumes and masks particularly high for each of the student 'Magician's Castle' players.

\section{RECOMMENDATIONS}

Worldwide, game design and play have been recognized as excellent tools in increasing creativity. Gamification in both its physical board form and digital form should be evaluated as a tool in future creativity studies. Also, social media platforms are now a common content delivery mechanism. Therefore, it is suggested that more educators make use of these mediums to develop creativity skills.

It is also suggested that future early learner creativity investigators add the element of 'space' to the mix of variables, as space plays a critical role in creating nurturing, as indoor play spaces of less than 25 square feet per child generally lead to increases in aggression and unfocused behavior for children. Time is also another element that should be sufficiently allocated, with this study determining that optimal playtime for Thai first graders was $15-25$ minutes per session.

\section{REFERENCES}

Abdyrov, A., Galiyev, T., Yessekeshova, M., Aldabergenova, S., \& Alshynbayeva, Z. (2016). On systems thinking and ways of building it in learning. International Journal 
of Environmental \& Science Education, 11(18), 11149-11161. https://files.eric.ed.gov/fulltext/EJ1120625.pdf

Ahmadpour, N., \& Mujembari, A. K. (2015). The impact of the Montessori Teaching Method on IQ levels of 5-year old children. Procedia - Social and Behavioral Sciences, 205, 122-127. http://dx.doi.org/10.1016/j.sbspro.2015.09.037

Alsawaier, R. S. (2018). The effect of gamification on motivation and engagement. The International Journal of Information and Learning Technology, 35(1), 56-79. https://doi.org/10.1108/ijilt-02-2017-0009

Arnold, R. D., \& Wade, J. P. (2017). A complete set of systems thinking skills. INSIGHT, 20(3), 9-17. https://doi.org/10.1002/inst.12159

Beghetto, R. A. (2019). Chapter 23: Creativity in the classroom. In J. C. Kaufman \& R. J. Sternberg (Eds.), The Cambridge handbook of creativity (pp. 447-464). https://doi.org/10.1017/cbo9780511763205.027

Best, J. W., \& Kahn, J. V. (2016). Research in education (10 $0^{\text {th }}$ ed.). Pesarson.

Biddle, K. A. G., Garcia-Nevarez, A., Henderson, W. J. R., \& Valero-Kerrick, A. (2014). Early Childhood Education: Becoming a Professional. SAGE Publications. https://tinyurl.com/xkxy7etb

Boonkua, A., Tuntinakorngul, A., \& Tungkunanan, P. (2020). Innovative organization's components in basic education institutions in Thailand. International Journal of Instruction, 13(3), 31-42. https://doi.org/10.29333/iji.2020.1333a

BTEC first children's care. (2006). Chapter 1: Understanding children's development. In BTEC first children's care, learning and development student book. Heinemann. https://tinyurl.com/56ag3cok

Bureekhampun, S., \& Tecchakanjanakij, K. (2019). Study and design kids toys to develop and art imagination for children 7 years old. Journal of Industrial Education, 18(3), 255 - 263. https://tinyurl.com/y5oyojno

Chiang, H. H. (2016). A study of interactions among ambiguity tolerance, classroom work styles, and English proficiency. English Language Teaching, 9(6), 61-75. https://doi.org/10.5539/elt.v9n6p61

Chuenban, P., Sornsaruht, P., \& Pimdee, P. (2021). How brand attitude, brand quality, and brand value affect Thai canned tuna consumer brand loyalty. Heliyon, 7(2), e04676. https://doi.org/10.1016/j.heliyon.2020.e04676

Dağgöl, G. D. (2017). Lifelong Learning: Not a 21st Century, but an omnitemporal skill. Journal of Social and Humanities Sciences Research, 4(12), 1254-1267. https://doi.org/10.26450/jshsr.207 
Davies, D., Jindal-Snape, D., Collier, C., Digby, R., Hay, P., \& Howe, A. (2013). Creative learning environments in education-A systematic literature review. Thinking Skills and Creativity, 8(80-91). https://doi.org/10.1016/j.tsc.2012.07.004

Dere, Z. (2019). Investigating the creativity of children in early childhood education institutions. Universal Journal of Educational Research, 7(3), 652-658. https://doi.org/10.13189/ujer.2019.070302

Dorninger, C., \& Schrack, C. (2008). Future learning strategy and ePortfolios in education. International Journal of Emerging Technologies in Learning, 3(1), 11-14. https://doi.org/10.1007/978-0-387-09729-9_35

Drosinos, K. J. (2006). Color selection in object drawings of young children. [Unplublished Master's thesis]. University of Maryland. https://tinyurl.com/y3wmuhoo

Drost, E. (2011). Validity and reliability in social science research. Education Research and Perpectives, 38(1), 105-123.

Eccles, J. S. (1999). The development of children ages 6 to 14. The Future of Children, 9(2), 30 - 44. https://doi.org/10.2307/1602703

Farokhi, M., \& Hashemi, M. (2011). The analysis of children's drawings: Social, emotional, physical, and psychological aspects. Procedia - Social and Behavioral Sciences, 30, 2219-2224. https://tinyurl.com/613trylb

Fleer, M. (2018). Child development in educational settings. Cambridge University Press.

Gielen, M. A. (2009). Essential concepts in toy design education: aimlessness, empathy and play value. International Journal of Arts and Technology, 3(1), 4-16. https://doi.org/10.1504/IJART.2010.030490

Gielen, M. A., \& van Leeuwen, L. (2013). Rebel by design: The merits of rebellious play and how to design for it. In IASDR 2013: Proceedings of the 5th International Congress of International Association of Societies of Design Research, Tokyo, Japan, 26-30 August 2013. International Association of Societies of Design Research.

Girmen, P., \& Kaya, M. F. (2019). Using the flipped classroom model in the development of basic language skills and enriching activities: Digital stories and games. International Journal of Instruction, 12(1), 555-572. https://doi.org/10.29333/iji.2019.12136a

Göttel. T. (2009). Culturia: Intercultural learning by designing games. In Creativity and the Child (pp. 167-177). Brill. https://doi.org/10.1163/9781848880061_017

Halupa, C. P. (2016). Chapter: Reaching "creating" in Bloom's Taxonomy the merging of heutagogy and technology in online learning. In Research on Creative Problem Solving Skills in Higher Education Handbook (pp. 429-449). IGI Global. https://doi.org/10.4018/978-1-7998-3022-1.ch002 
Honig, A. S. (2020). How to Promote Creative Thinking. Scholastic. https://tinyurl.com/ypuw2mzw

Im, H., Hokanson, B., \& Johnson, K. K. P. (2015). Teaching creative thinking skills: A longitudinal study. Clothing and Textiles Research Journal, 33(2), 129-142. https://doi.org/10.1177/0887302X15569010

Isaacs, B. (2018). Understanding the Montessori Approach: Early years education in practice ( $2^{\text {nd }}$ ed.). David Fulton Publishers.

Ismaeel, D. A., \& Al Mulhim, E. N. (2019b). Influence of augmented reality on the achievement and attitudes of ambiguity tolerant/intolerant students. International Education Studies, 12(3), 59-70. https://doi.org/10.5539/ies.v12n3p59

Jai-ai, N., Seviset, S., \& Saribut, U. (2019). The study and development for the set of activity table to support the activity learning of grade 4 students by Department of Arts. Advances in Computer Science Research, 91, 432-439. https://doi.org/10.2991/msbda19.2019.68

Karpova, E., Marcketti, S. B., \& Barker, J. (2011). The efficacy of teaching creativity: Assessment of student creative thinking before and after exercises. Clothing and Textiles Research Journal, 29(1), 52-66. https://doi.org/10.1177/0887302x11400065

Laal, M., \& Salamati, P. (2012). Lifelong learning; why do we need it? Procedia Social and Behavioral Sciences, 31, 399-403. https://doi.org/10.1016/j.sbspro.2011.12.073

Lowenfeld, V. \& Brittain, W. L. (1987). Creative and mental growth (8th ed). PrenticeHall.

Meerum-Terwogt, M., \& Hoeksma, J. B. (1995). Color and emotions: preferences and combinations. Journal of Genetic Psychology, 122(1), 5-17.

Mcfarlane, P. (2013). Dramatherapy: raising children's self-esteem and developing emotional stability. David Fulton Publishers.

Ministry of Edcuation. (2013). Nurturing early learners: A curriculum for kindergartens in Singapore. https://tinyurl.com/1 cm7guqj

Morse, K. (2017, June 16). Developing creative thinking skills through art. National Association for Gifted Children. https://tinyurl.com/y74sgwzq

Okulova, L . P. (2020). An ergonomic approach to higher education of psychology and pedagogy students. Revista espacios, 41(2), 13-23. https://tinyurl.com/8uvm88je

P1mdee, P. (2020). Antecedents of Thai student teacher sustainable consumption behavior. Heliyon, 6(8), e04676. https://doi.org/10.1016/j.heliyon.2020.e04676

Price, P. C., Jhangiani, R., \& Chiang, I-C., A. (2019). Chapter 5: Psychological measurement. Research Methods in Psychology (2 ${ }^{\text {nd }}$ Canadian edition, pp. 75-97). Pressbooks.com. https://tinyurl.com/yy3ouzrh 
Radiah (2020). Development of biology test of creative thinking-Torrance tests (BTCTTT) assessment to improve students' creative thinking skills. JISAE: Journal of Indonesian Student Assessment and Evaluation, 6(1), 73-83. https://doi.org/10.21009/jisae.061.06

Riche, T. (2014, February 6). 22 Simple ideas for harnessing creativity in the elementary classroom. Edutopia. https://tinyurl.com/1202q7dg

Sandborn, D. (2014, July 25). Play: One of the most important factors in a child's development. Michigan State University Extension. https://tinyurl.com/ynclez27

Sawyer, C. B., \& Willis, J. M. (2011). Introducing digital storytelling to influence the behavior of children and adolescents. Journal of Creativity in Mental Health, 6, 274283. https://doi.org/10.1080/15401383.2011.630308

Sefton-Green, J., Thomson, P., Jones, K., \& Bresler, L. (Eds.). (2011). The Routledge international handbook of creative learning. Routledge. https://tinyurl.com/2fyx $9 \mathrm{vlk}$

Shahsavar, Z., \& Hoon, T. B. (2011). Does cognitive style affect bloggers' attitude in an online learning environment? GEMA Online Journal of Language Studies, 11(1), 159171. http://journalarticle.ukm.my/996/

Smith, P. K., Cowie, H., \& Blades, M. (2015). Understanding children's development (6th ed.). Wiley.

Su, C. H., \& Cheng, C. H. (2015). A mobile gamification learning system for improving the learning motivation and achievements. Journal of Computer Assisted Learning, 31(3), 268-286. https://doi.org/10.1111/jcal.12088

Tayebinik, M., \& Puteh, M. (2013). The role of ambiguity tolerance in participation in online EFL courses. British Journal of Educational Technology, 44(6), E207-E208. https://doi.org/10.1111/bjet.12087

Vargas, A. L., \& Castro, J. A. (2020). Packaging design: Origami based learning. EDULEARN20 Proceedings. https://doi.org/10.21125/edulearn.2020.1588

Wormald, P. W., \& Rodber, M. (2008). Aligning industrial design education to emerging trends in professional practice and industry. Journal of Design Research, 7(3), 294-303. https://doi.org/10.1504/jdr.2008.024196

Yarbrough. N. D. (2016). Assessment of creative thinking across cultures using the Torrance Tests of Creative Thinking (TTCT): Translation and validity issues. Creativity Research Journal, 28(2), 154-164. https://doi.org/10.1080/10400419.2016.1162571

Yuktirat, C., Sindhuphak, A., \& Kiddee, K. (2018). M-learning for the art of drawing: Informal learning for a digital age. International Journal of Interactive Mobile Technologies, 12(5), 152-168. https://doi.org/10.3991/ijim.v12i5.9207 